Original Research Paper

\title{
Immunological Characteristics of Winter Wheat Lines with Resistance to Rust Diseases in Kazakhstan
}

\author{
${ }^{1,2}$ Saltanat Bakytzhanovna Dubekova, ${ }^{1,2}$ Amangeldy Taskalievich Sarbaev, ${ }^{1,2}$ Aikerim Asylbekkyzy Ydyrys, \\ ${ }^{1}$ Aidarkhan Kadyrkhanovich Eserkenov and ${ }^{1}$ Sholpan Orazovna Bastaubaeva
}

${ }^{I}$ Kazakh Research Institute of Agriculture and Plant Growing, Almaty, Kazakhstan

${ }^{2}$ Kazakh National Agrarian Research University, Almaty, Kazakhstan

\section{Article history}

Received: 24-08-2021

Revised: 26-10-2021

Accepted: 12-11-2021

Corresponding Author: Aikerim Asylbekkyzy Ydyrys

Kazakh Research Institute of

Agriculture and Plant Growing,

Kazakh National Agrarian

Research University, Almaty,

Kazakhstan

Email: kerem.ydyrys@mail.ru

\begin{abstract}
The growing spread of particularly dangerous diseases (variations of rust) in the grain-bearing countries raises fears of the harmfulness of phytopathogens increasing. In the years favorable for their development, a sharp decrease in the productivity of the ear and the quality of the grain is observed. The high potential of the pathogen to produce new aggressive disease variations makes most grain varieties susceptible to this pathogen. To determine the immunological value of breeding lines of winter wheat, we conducted immunological studies on the experimental base of the Kazakh Research Institute of Agriculture and Plant Growing in 2015-2020. Under the conditions of artificial infectious background at a specialized facility, a targeted immunological assessment was carried out on 28 lines of irrigated winter bread wheat, 24 lines of rainfed winter bread wheat and 20 lines of winter durum wheat. An artificially infectious background was created using a population of rust uredospores: $P$. striiformis, $P$. triticina, $P$. graminis. According to the reaction to the pathogen population, the breeding lines were divided into resistance types according to the established disease resistance scales. The authors analyzed the state of resistance of the winter wheat line of Kazakhstan breeding to the rust population in the conditions of the southeast of Kazakhstan. The paper characterizes the reactions of breeding lines to rust pathogens $P$. striiformis, $P$. triticina, $P$. graminis. Based on the immunological assessment, two lines of common wheat, one line of soft wheat and four lines of durum wheat with resistance were isolated using a reaction to $P$. striiformis with no signs of disease. Five lines of common wheat showed moderate resistance to this pathogen. The other $(79.2 \%)$ breeding lines of winter wheat were characterized as moderately susceptible and susceptible to the rust pathogen. The identified breeding lines combine high economically valuable traits (productivity) and resistance to yellow rust and are of the greatest immunological value. This proves the prospects and expediency of their further use in the breeding improvement of the local agroecotype of winter wheat.
\end{abstract}

Keywords: Winter Wheat, Lines, Breeding, Immunity, Resistance

\section{Introduction}

Wheat is one of the most important strategic cultures in Kazakhstan to ensure the food security of the country. Meanwhile, harmful types of rust (Puccinia) develop and spread annually on its crops, such as yellow rust $(P$. striiformis f. sp. tritici), leaf rust ( $P$. triticina f. sp. tritici) and stem rust $(P$. graminis $f$. sp. tritici) (Koishybaev, 2010; 2018). The pathogens of the disease affect all plant above-ground organs, which leads to a reduction in the photosynthetic activity of vegetative organs, the quality of seeds and loss of yield from 10 to $70 \%$, depending on the dynamics of the development of infection and susceptibility of the variety (Koishybaev, 2010; 2018; Chen, 2005). The emergence of new species and the ability of pathogens to migrate aerogenically over long distances make the majority of crops susceptible to phytopathogens (Koishybaev, 2010; 2018).

It is known that the dynamics of rust development (incubation period, sporulation, infection) are affected by the main climatic factors, like humidity, temperature and wind. The ongoing global changes in climatic factors lead 
to the threat of the emergence of new, mutated rust pathotypes adapted to changing environmental conditions, which can result in serious epidemics, as it was noted in the central and eastern parts of the United States and Canada (Lyon and Broders, 2017). Therefore, this increases the risk of the emergence of virulent race pathogens which cause epiphytosis in wheat-producing countries, including Kazakhstan. Thus, in recent years, aggressive races of yellow rust have been discovered in the countries of Europe, Africa and Central Asia (Hovmoller, 2017). As a result of the defect in the stability of the Yr9 and Yr27 genes caused by Puccinia striiformis, high-yielding varieties in many countries were subjected to large epiphytosis (Solh et al., 2012). Thus, in 2017, the epidemic of yellow rust was observed on several continents. By that time, the Global Rust Reference Center (GRRC) had identified several different types of yellow rust in Argentina. Two of them were identical pathotypes, first discovered in Europe and North Africa in 2015-2016 (Hovmøller et al., 2018). Leaf rust (Puccinia triticina $f$. sp. tritici) also negatively affects the phytopathological situation of crops, causing annual crop losses that reach 5-10\% and in the years of epiphytosis up to 50-70\% (Kurmanbayeva et al., 2021; Prasad et al., 2020). Acute development of stem rust (Puccinia graminis $f$. $s p$. tritici) is caused by the high aggressiveness of this pathogen. It can almost destroy wheat crops. Epiphytotic outbreaks have been recorded on almost all continents (Volkova et al., 2020). It is known that rust species are found on the territory of Kazakhstan almost annually, except for extremely dry years (Koishybaev, 2018).

International programs have been developed to avoid or minimize the risk of grain rust. Since 2008, Food and Agriculture Organization (FAO) has been implementing a global wheat rust control program to provide strategic and technical assistance to interested countries, national and international partners. In particular, it has been collaborating with the International Center for Agricultural Research in the Dry Areas (ICARDA), the International Maize and Wheat Improvement Center (CIMMYT), the International Fund for Agricultural Development (IFAD), Cornell University and Aarhus University in the context of the Borlaug Global Rust Initiative (BGRI) (FAO, 2017).

There are a large number of resistance genes that ensure successful breeding (McIntosh et al., 2017); however, the search for new sources of resistance and the evaluation of breeding material is of particular importance, due to changes in virulence in the pathogen population (Park et al., 2011). Based on the molecular screening of wheat varieties, scientists have identified carriers of the genes responsible for resistance to yellow rust (Yr 5, Yr 10, Yr 15) and leaf rust ( $\mathrm{Lr} 26, \mathrm{Lr} 34)$ (Kokhmetova et al., 2014a). New races of the pathogen have also been identified from the samples of spores of the Kazakh rust population (Rsaliyev, 2011; Rsaliyev et al., 2020, 2013; Rsaliyev and Rsaliyev, 2018). Meanwhile, the threat of rust spread can be minimized by quickly detecting the disease and producing and supplying grains of new, high-yielding varieties with increased immunological indicators. The introduction of such varieties into production will reduce the cost of various methods of protection against the pathogen. In this regard, breeders and immunologists aim to breed high-yielding and disease-resistant wheat varieties that are not inferior in their economically valuable characteristics to the best Kazakh and foreign achievements.

For many years, within the framework of national and international programs, Kazakh scientists have researched the creation and improvement of varieties characterized by high yield, improved quality and resistance to biotic and abiotic factors (Urazaliev et al., 2018; Urazaliev, 2019; Morgounov et al., 2020). The effectiveness of breeding works in Kazakhstan is marked by a large number of adapted, plastic high-yielding varieties of various crops with a complex of economically valuable characteristics (Urazaliev, 2011; 2019). At the same time, the constant systematic study of the local breeding of the world collection for resistance to the pathogen population becomes a prerequisite for the correct choice of the source material when creating new varieties. In this regard, the study of disease resistance features in promising lines is a valuable scientific work for the breeding of winter wheat for immunity. At the same time, it is important to assess the resistance to diseases of the Competitive Variety Testing (CVT) line, which is the last stage of the breeding test, where lines are given a complete evaluation for economically valuable characteristics (Urazaliev, 2011; Goncharov and Goncharov, 1993). Every year, within the framework of breeding programs, we conducted comprehensive assessments of Kazakh and foreign lines and varieties for resistance to particularly harmful diseases in the region (Ydyrys et al., 2020; Dubekova et al., 2020; Esimbekova et al., 2019). We have identified the sources and donors of resistance, which are of fundamental and applied importance in expanding genotypic diversity in wheat breeding.

The purpose of our study was to determine the breeding and immunological value of promising winter wheat lines for rust resistance in the conditions of the southeast of Kazakhstan.

\section{Materials and Methods}

The work (2015-2020) on the study of breeding lines was carried out at the experimental base of Kazakh Research Institute of Agriculture and Plant Growing (KazNIIZiR). In the field, on an artificially infectious background, promising, highly productive breeding lines from the CVT nursery: 28 lines of selection of irrigated winter bread wheat and 24 lines of rainfed winter bread wheat, as well as 20 lines of winter durum wheat were tested for immunological features. The lines were studied in a specialized hospital in two directions - irrigation and rainfed. Plots in the study of breeding lines with a size of 
$1 \mathrm{~m}^{2}$ are arranged using a standard placement method. The local varieties Almaly, Steklovidnaya 24, Bogarnaya 56, showing Moderate Susceptibility (MS) and Susceptibility $(\mathrm{S})$ to the pathogen under conditions of an artificial infectious background were used as standards. Besides, the foreign Morocco variety highly susceptible to the pathogen was used as an indicator and a seed pool.

Inoculation of the studied lines was carried out in the spring from the tillering phase to the exit of the culture into the tube with urediniospores of $P$. striiformis, $P$. triticina, $P$. graminis mixed with talc in a ratio of $1: 100$, with a load of $20 \mathrm{mg}$ of spores/ ${ }^{\mathrm{m} 2}$. Infection was carried out in the evening hours after rains, in the most favorable conditions for infection: In calm weather, at the optimum air temperature for the development of rust pathogens (not higher than $25^{\circ} \mathrm{C}$ for $P$. striiformis and not lower than $20^{\circ} \mathrm{C}$ for $P$. triticina and P. graminis) (Roelfs et al., 1992).

Evaluation and selection for the stability of promising lines were carried out according to the method adopted in CIMMYT. The first accounting of diseases was carried out at the beginning of their manifestation, the subsequent ones were performed at an interval of 10-12 days before the onset of the phase of milky ripeness of grain. The type of reaction and the degree $(\%)$ of plant damage were used as criteria for the resistance of the line to the pathogen. The type of reaction was determined according to the recommended scale CIMMYT (RSG, 1986): 0 (immune) with no symptoms of the lesion; R (resistant) with small individual necrotic zones, there are no pustules; MR (Moderately Resistant) with small pustules surrounded by chlorotic and necrotic spots; MS (moderately susceptible) with medium-sized pustules, no necrotic spots, but possible chlorotic spots; and Susceptible (S) with large pustules, without chlorosis and necrosis. The degree of plant damage was assessed as a percentage according to the R. F. Peterson scale modified by Cobb with the gradation of 5, 10, 20, 40, 60... 100\% (Peterson et al., 1948).

The meteorological conditions during the study period (2015-2016, 2019) were relatively wet (periodic precipitation, prolonged and frequent dews), which generally favored the manifestation and development of the pathogen and the growing seasons of 2017-2018 were relatively dry for the development of diseases in the region. In the first half of the growing season of 2020 , the weather was relatively cool with an abundance of dew, which contributed to the increased manifestation of the disease, but later in the second half of the growing season, there was a rapid increase in air temperature, which restrained the rate of development of yellow rust.

\section{Results}

During the study of the breeding material obtained from the CVT lines of winter wheat, scientifically based data were obtained on their resistance to the rust population (Fig. 1). The analysis of the state of resistance to rust species for the CVT lines of winter wheat was performed based on the assessment of the populations of $P$. striiformis, $P$. triticina and $P$. graminis on them.

Immunological evaluation of breeding lines of winter bread wheat. Against an artificially infectious background of infection, the standard (Almaly) variety was marked by an MS reaction, while the Steklovidnaya 24, Bogarnaya 56 and the foreign standard (Morocco) variety were affected by the pathogen up to $70-100 \%$, which indicated that a strong infectious background had been created, acceptable for an objective assessment and selection of the corresponding lines. At the same time, most of the lines under consideration were classified as MS or S (Table 1).

Depending on the reaction to rust pathogens ( $P$. striiformis, $P$. triticina $P$. graminis), the breeding lines were ranked immune (0), Resistant (R), Moderately Resistant (MR), Moderately Susceptible (MS) and Susceptible (S). All 24 CVT lines of the rainfed wheat were affected by rust pathogens up to $70-100 \%$, showing the type of MS-S reaction.

At the same time, among the tested 28 CVT lines of irrigated wheat bred at the nursery, with the immune response, $2(7,1 \%)$ demonstrated lack of signs of yellow rust (Puccinia striiformis); $1(3,6 \%)$ showed $\mathrm{R}$ and 5 (17.8\%) showed MR. 16 lines $(57.1 \%)$ demonstrated MS and $4(14,3 \%)$ lines showed S. In this nursery, no lines demonstrating $\mathrm{R}$ to pathogens of leaf rust (Puccinia triticina) and stem rust (Puccinia graminis) were found. MR to leaf rust was noted only in 4 lines (14.3\%) and MR to stem rust was found in 3 lines (10.7\%) (Fig. 2).

Analyzing the obtained data it can be noted that the immunological potential of the breeding lines, requires annual quality study and saturation breeding kennels genetically diverse donors of resistance, since most of the subjects, lines of bread wheat (T. aestivum) of the irrigated type $(71.4 \%)$ and rainfed type $(100 \%)$ were Susceptible (MS-S) to the agents of rust.

\section{Immunological Evaluation of Breeding Lines of Winter Bread Wheat}

In addition, the breeding lines of the CVT nursery of winter durum wheat ( $T$. durum) were affected by different rust species and the degree of development varied from low (less than 20\%) to high (more than 50\%). Of the tested 20 breeding lines of durum wheat 4 showed $\mathrm{R}$ and 3 lines showed MR to yellow rust, while 12 lines showed MS and 1 line showed S. Also, 1 line demonstrated MR to leaf rust. CVT lines of durum wheat demonstrating $\mathrm{R}$ to all types of rust (yellow, leaf, stem rust) were not found. 
Of the total number of tested material, the number $(\%)$ of lines Susceptible (MS-S) to types of rust equals, for bread wheat: $84.6 \%$ to yellow rust; $92.3 \%$ to leaf rust; $94.2 \%$ to stem rust and for durum wheat: $65 \%$ to yellow rust, $95 \%$ to leaf rust and $100 \%$ to stem rust (Fig. 3).

A high percentage of susceptible lines to rust pathogens can be considered as a signal for breeders and immunologists. It is necessary to analyze and systematically carry out developments to this real threat, given that most local wheat varieties and lines are very susceptible to this particularly dangerous pathogen, which in the years of epiphytotics can lead to a complete loss of yield and plant death.

At the same time, the resistant lines found among the tested material with no signs of diseases show the significance of the study and confirm the value of genetic resistance in ensuring the protection of the crop from the pathogen. The found stable lines represent a high breeding significance for immunity (Fig. 4).

It is important to note that, breeding lines of bread wheat (T. aestivum): 4/2109; 9/7/128 gen and 10/60 F5 N23 Kupava 7 significantly exceeded the standard varieties Almaly, Steklovidnaya 24, Bogarnaya 56 in terms of resistance to yellow rust, under conditions of an artificially infectious background.
Immunological signs appeared somewhat differently on durum wheat (T. durum) lines. This is probably due to the peculiarities of the genomic structure of the crop and the pathogen. Thus, $20 \%$ of the breeding material was resistant to yellow rust, while more than half $(60 \%)$ of the studied durum wheat material was affected by the pathogen (MS) at the level of the Kazakhstanskaya yantarnaya standard.

At the level of the Susceptible (S) of the standard foreign variety (Morocco), 11 lines of wheat $(5,7 \%)$ were affected by yellow rust ( $P$. striiformis), 35 lines (18.2\%) by leaf rust ( $P$. triticina) and 33 lines $(17.2 \%)$ by stem rust ( $P$. graminis), which characterizes their weak significance for breeding for immunity.

The presented information confirms the special danger of rust for grain-growing regions of the country and the need to create promising varieties that combine high productivity and resistance to this pathogen. In this regard, it is advisable to constantly study promising lines, analyze and obtain scientifically-based information, to strengthen breeding programs. The immunological assessment and selection of resistant forms, carried out to increase the immunological potential of the wheat variety being created, will in the future contribute to reducing the large-scale use of fungicides and negative environmental consequences.

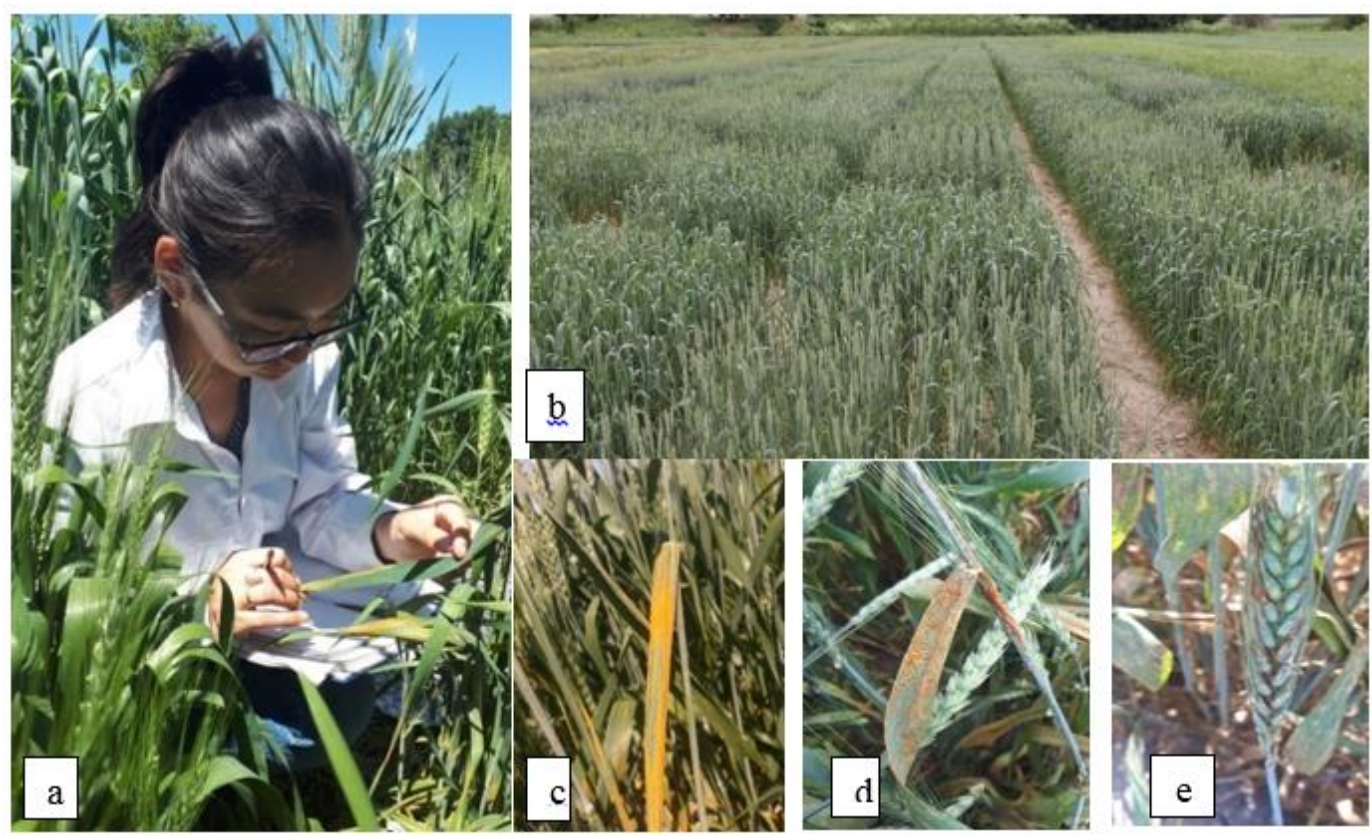

Fig. 1: Immunological field studies on an artificially infectious background; a: Observation and assessment for resistance to the pathogens, June 2020; b: Breeding lines of winter wheat in the experimental area; c: Yellow rust (P. striiformis f. sp. tritici) on the leaf; a decrease in photosynthesis; d: Simultaneous inoculation of bread winter wheat with leaf rust ( $P$. triticina f. sp. tritici) and stem rust ( $P$. graminis f. sp. tritici), d: An infected ear of durum winter wheat with stem rust. (@ photos were made by Dubekova et al., 2020) 


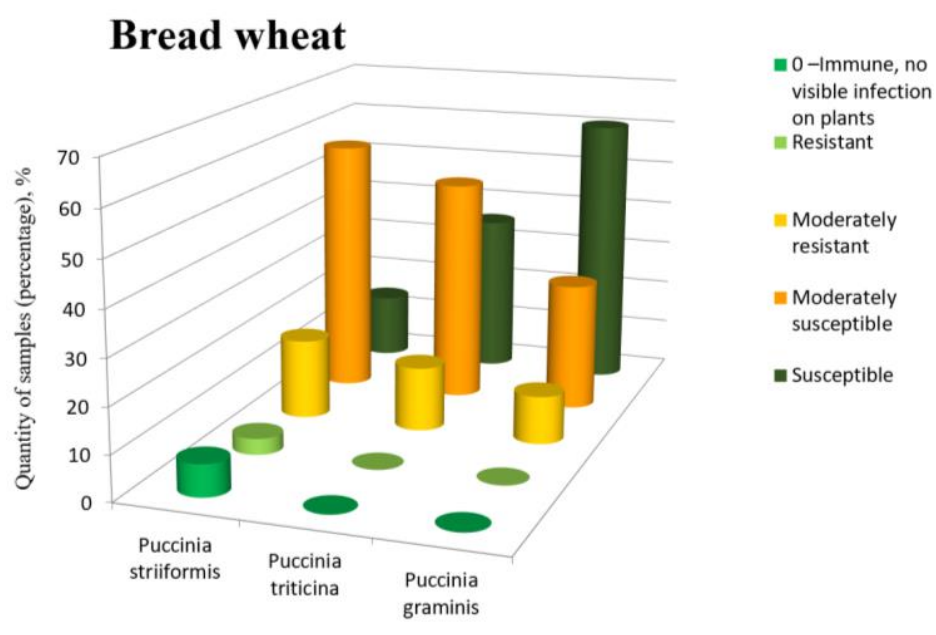

Fig. 2: Distribution of the CVT line of winter bread wheat of the irrigated type, according to the reaction to rust pathogens (average value for 2015-2020)

B Bread wheat $\quad$ Durum wheat

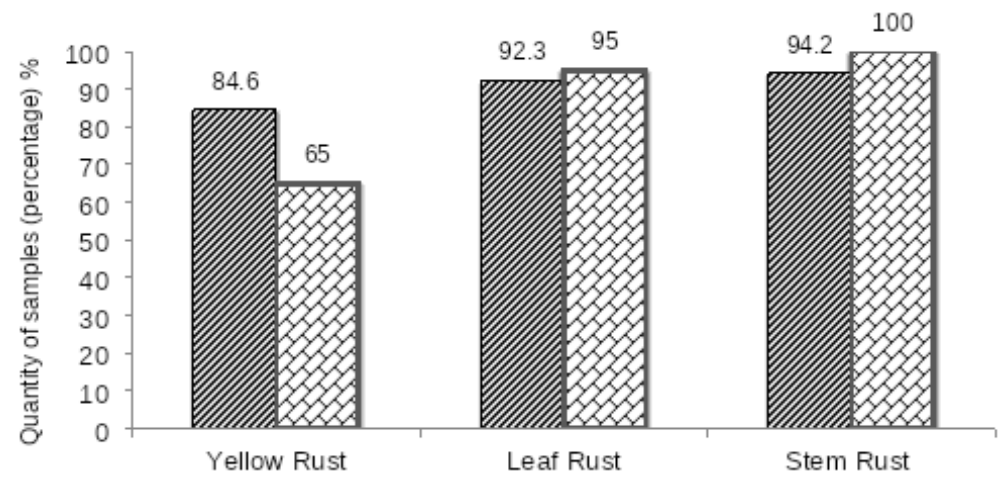

Fig. 3: The incidence of rust species in breeding lines of bread and durum wheat (artificially infectious background, average value for 2015-2020)

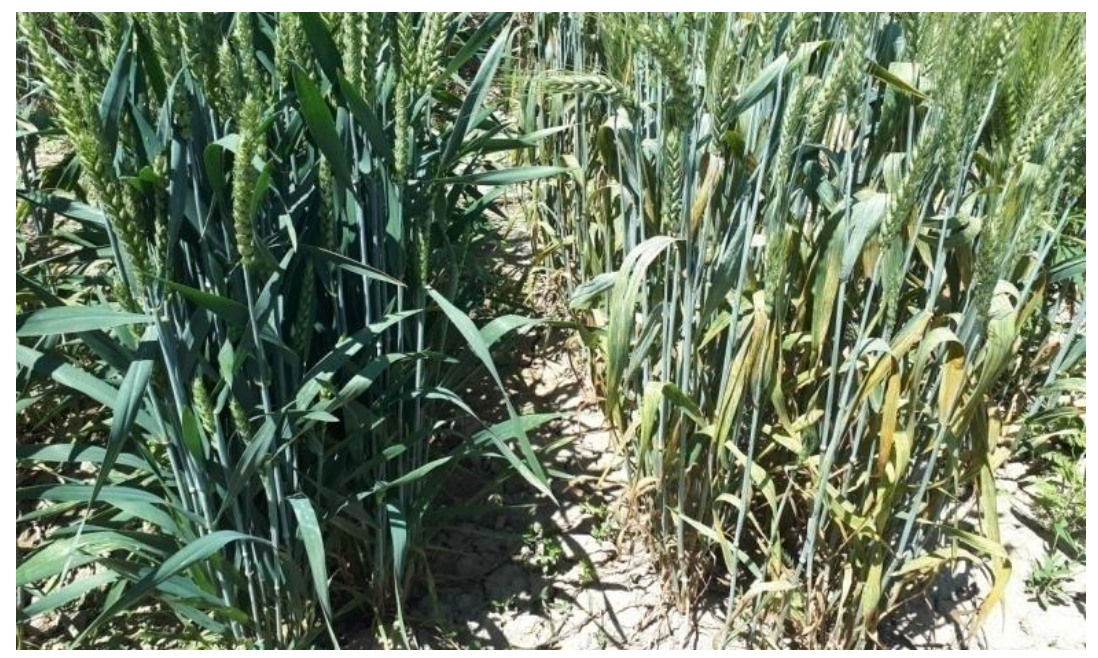

Fig. 4: The difference in the reaction for resistance to yellow rust (Puccinia striiformis) between breeding lines. June 2020. (@) photos were made by Dubekova et al., 2020) 
Table 1: Immunological characteristics of the CVT line of winter bread wheat by the reaction to rust populations (average indicators of infectability on an artificially infectious background, 2015-2020)

\begin{tabular}{|c|c|c|c|}
\hline \multirow[b]{2}{*}{ Catalogue No., lines } & \multicolumn{3}{|c|}{ Rust population infectability, \%/type of reaction } \\
\hline & Puccinia striiformis & Puccinia triticina & Puccinia graminis \\
\hline \multicolumn{4}{|l|}{ CVT of the irrigated wheat } \\
\hline SWW1/904 & 20MS & $90 \mathrm{~S}$ & $25 \mathrm{MS}$ \\
\hline $4 / 2109$ & 0 & $10 \mathrm{MR}$ & $10 \mathrm{MR}$ \\
\hline $3 / 18408-7$ & $30 \mathrm{~S}$ & $90 \mathrm{~S}$ & $30 \mathrm{~S}$ \\
\hline $18410-1$ & $30 \mathrm{~S}$ & $15 \mathrm{MS}$ & $20 \mathrm{~S}$ \\
\hline 7/18416-4 & $10 \mathrm{MS}$ & $25 \mathrm{~S}$ & $20 \mathrm{~S}$ \\
\hline $21115-6$ & $25 \mathrm{MS}$ & 30MS & $30 \mathrm{~S}$ \\
\hline $43 / 21427-2$ & $15 \mathrm{MR}$ & 20MR & $10 \mathrm{MS}$ \\
\hline $59 / 21427-3$ & $15 \mathrm{MS}$ & $25 \mathrm{MS}$ & $15 \mathrm{MS}$ \\
\hline 60/20948-1 & $10 \mathrm{MS}$ & 20MS & $20 \mathrm{~S}$ \\
\hline 9/7/128 gene & 0 & $5 \mathrm{MR}$ & $5 \mathrm{MR}$ \\
\hline 10/60 F5 N23 Kupava 7 & $5 \mathrm{R}$ & $10 \mathrm{MR}$ & $15 \mathrm{MR}$ \\
\hline 9/20197-17 & $15 \mathrm{MS}$ & 30MS & $20 \mathrm{MS}$ \\
\hline $10 / 20403-2$ & $20 \mathrm{MS}$ & 30MS & $25 \mathrm{~S}$ \\
\hline $12 / 20977-13$ & $10 \mathrm{MS}$ & $25 \mathrm{MS}$ & $20 \mathrm{MS}$ \\
\hline $15 / 20942-7$ & $20 \mathrm{~S}$ & 30MS & $10 \mathrm{MS}$ \\
\hline $17 / 21095-2$ & $10 \mathrm{MR}$ & $25 \mathrm{MS}$ & $15 \mathrm{MS}$ \\
\hline $18 / 21098-4$ & $25 \mathrm{~S}$ & $50 \mathrm{~S}$ & $20 \mathrm{~S}$ \\
\hline $22 / 21106-1$ & $15 \mathrm{MR}$ & $20 \mathrm{MS}$ & $40 \mathrm{~S}$ \\
\hline $21113-1$ & $20 \mathrm{MS}$ & $60 \mathrm{~S}$ & 20MS \\
\hline $34 / 19187-3$ & $10 \mathrm{MR}$ & $25 \mathrm{MS}$ & $15 S$ \\
\hline $35 / 20060-2$ & $5 \mathrm{MR}$ & $15 \mathrm{MS}$ & $20 \mathrm{~S}$ \\
\hline $37 / 20948-8$ & $10 \mathrm{MS}$ & $25 \mathrm{MS}$ & $60 \mathrm{~S}$ \\
\hline $22 / 20521-1$ & $15 \mathrm{MS}$ & $60 \mathrm{~S}$ & $30 \mathrm{~S}$ \\
\hline $33 / 21097$ & $10 \mathrm{MS}$ & $20 \mathrm{~S}$ & $25 \mathrm{~S}$ \\
\hline $36 / 21172-2$ & $15 \mathrm{MS}$ & $25 \mathrm{MS}$ & $30 \mathrm{~S}$ \\
\hline $3 / 18628-3$ & $10 \mathrm{MS}$ & $100 \mathrm{~S}$ & $50 \mathrm{~S}$ \\
\hline $4 / 18723-7$ & $10 \mathrm{MS}$ & $40 S$ & $30 \mathrm{~S}$ \\
\hline $18403-5-4$ & $15 \mathrm{MS}$ & $70 \mathrm{~S}$ & $30 \mathrm{~S}$ \\
\hline Almaly & $15 \mathrm{MS}$ & $80 \mathrm{~S}$ & $20 \mathrm{~S}$ \\
\hline Morocco & $100 \mathrm{~S}$ & $20 \mathrm{~S}$ & $25 \mathrm{~S}$ \\
\hline \multicolumn{4}{|l|}{ CVT of the rainfed wheat } \\
\hline $19059-21$ & $20 \mathrm{MS}$ & $100 \mathrm{~S}$ & $80 \mathrm{~S}$ \\
\hline $19251-2$ & $15 \mathrm{MS}$ & $50 \mathrm{~S}$ & $60 \mathrm{~S}$ \\
\hline $19488-22$ & $20 \mathrm{~S}$ & $50 \mathrm{~S}$ & $50 \mathrm{~S}$ \\
\hline $19670-1$ & $10 \mathrm{MS}$ & $70 \mathrm{~S}$ & $25 \mathrm{~S}$ \\
\hline $19980-4$ & $25 \mathrm{MS}$ & $80 \mathrm{~S}$ & $60 \mathrm{~S}$ \\
\hline $19980-6$ & $20 \mathrm{MS}$ & $30 \mathrm{~S}$ & $20 \mathrm{MS}$ \\
\hline $20060-3$ & $40 \mathrm{~S}$ & $30 \mathrm{~S}$ & $20 \mathrm{~S}$ \\
\hline $20061-12$ & $30 \mathrm{~S}$ & $40 \mathrm{~S}$ & $40 \mathrm{~S}$ \\
\hline $20009-6$ & $20 \mathrm{MS}$ & $30 \mathrm{~S}$ & $20 \mathrm{MS}$ \\
\hline $20114-13$ & $20 \mathrm{~S}$ & $30 \mathrm{~S}$ & $40 \mathrm{~S}$ \\
\hline 20114-16 & $25 \mathrm{MS}$ & $80 \mathrm{~S}$ & $25 \mathrm{~S}$ \\
\hline $20156-3$ & $15 \mathrm{MS}$ & $20 \mathrm{~S}$ & $30 \mathrm{~S}$ \\
\hline $20156-4$ & $25 \mathrm{~S}$ & $40 \mathrm{~S}$ & $20 \mathrm{~S}$ \\
\hline 20232-14 & $15 \mathrm{MS}$ & $50 \mathrm{~S}$ & $20 \mathrm{MS}$ \\
\hline $20388-3$ & $10 \mathrm{MS}$ & $30 \mathrm{~S}$ & $20 \mathrm{MS}$ \\
\hline $20388-7$ & 20MS & $100 \mathrm{~S}$ & $35 \mathrm{MS}$ \\
\hline 20389 & $30 \mathrm{~S}$ & $60 \mathrm{~S}$ & $20 \mathrm{MS}$ \\
\hline $20389-1$ & $70 \mathrm{~S}$ & $100 \mathrm{~S}$ & $20 \mathrm{MS}$ \\
\hline $20389-2$ & $25 \mathrm{MS}$ & $25 \mathrm{MS}$ & $15 \mathrm{MS}$ \\
\hline 20389-3 & $10 \mathrm{MS}$ & $40 \mathrm{~S}$ & $15 \mathrm{MS}$ \\
\hline $20841-2$ & 30MS & $30 \mathrm{~S}$ & $20 \mathrm{~S}$ \\
\hline 20841-17 & $25 \mathrm{MS}$ & $40 \mathrm{~S}$ & $25 \mathrm{~S}$ \\
\hline $19962-5$ & $15 \mathrm{MS}$ & $100 \mathrm{~S}$ & $15 \mathrm{MS}$ \\
\hline $18952-1$ & $25 \mathrm{MS}$ & $50 \mathrm{~S}$ & $20 \mathrm{~S}$ \\
\hline Steklovidnaya 24 & $30 \mathrm{MS}$ & $100 \mathrm{~S}$ & $20 \mathrm{~S}$ \\
\hline Bogarnaya 56 & $40 \mathrm{~S}$ & $50 \mathrm{~S}$ & $20 \mathrm{MS}$ \\
\hline Morocco & $100 \mathrm{~S}$ & $40 \mathrm{~S}$ & $30 \mathrm{~S}$ \\
\hline
\end{tabular}

Notes: 0: Immune, no visible infection on plants; R: Resistant; MR: Moderately Resistant; MS: Moderately Susceptible; S: Susceptible 


\section{Discussion}

Immunological characteristics of the breeding lines studied by us are necessary for improving and deepening breeding research to determine the most valuable high-yielding line samples with resistance to diseases.

Comparative results on immunological parameters of breeding materials of winter soft and durum wheat show that, during the years of the study, yellow rust ( $P$. striiformis) was strongly pronounced for the line of bread wheat, where the degree of infectability of this pathogen was up to $70 \mathrm{~S}$, whereas on the lines of durum wheat, the infectability varied from $10 \mathrm{MS}$ to $30 \mathrm{~S}$. At the same time, higher levels of Susceptibility (MS-S) to leaf rust ( $P$. triticina) and stem rust $(P$. graminis) have been discovered for durum wheat. Differences in susceptibility among lines within the region are known to be associated with the genetic structure of the plant host and the pathogen population (Qi et al., 2019), as well the peculiarities of the climatic condition in the test.

In general, most of the evaluated lines were maximally affected by types of rust, under conditions of an artificially infectious background. According to the literature data, during the period of our study (2015-2020) and in other grain-growing countries, epiphytotic developments of this pathogen were observed. Thus, mutated races of the pathogen $P$. striiformis were found in the countries of Europe, Africa and Central Asia. In 2016, a strain of yellow rust AF2012, previously common in Afghanistan, was discovered in Ethiopia and Uzbekistan, where it destroyed thousands of hectares of wheat (Hovmoller, 2017). In 2013, virulent races of the $\mathrm{Lr} 14$ a gene were first registered in Spain. In 2012-2016, epiphytotic yellow rust was observed in many territories of the countries, due to the invasion of the Warrior race. Despite the availability of effective fungicides and resistant varieties to combat rust diseases, aggressive races of this pathogen continue to threaten wheat production in grain-growing countries. In 2016, stem rust caused epiphytosis on durum wheat in Sicily (Italy), where the climatic conditions are similar to those in the south and east of Spain (Martinez-Moreno and Solís, 2019). International cooperation and systematic alerts are needed to characterize the resistance of varieties of various origins, to control the movement and virulence of wheat rust pathogens.

As a result of the study, all durum wheat samples were highly susceptible to the stem rust pathogen ( $P$. graminis), while the susceptibility of soft wheat was $94.2 \%$ of the samples. The susceptibility to the population of brown rust ( $P$. triticina) of soft and durum wheat samples was 92.3 and $95 \%$, respectively. When the test material was inoculated with a population of yellow rust ( $P$. striiformis) $65 \%$ of the soft wheat samples showed susceptibility, while in durum wheat, this indicator was $84.6 \%$. Analysis of the state of resistance of the breeding lines shows that T. aestivum samples were more affected by the yellow rust population than T. durum samples.
Thus, lines (4/2109; 9/7/128 gene; 10/60 F5 N23 Kupava 7) of common wheat and four lines of durum wheat were distinguished by resistance $(\mathrm{R})$ to $P$. striiformis. The soft wheat lines 43/21427-2; 17/21095-2; 22/21106; $34 / 19187-3$; 35/20060-2 were distinguished by moderate resistance (MR) to this pathogen. This indicates the presence of highly efficient $\mathrm{Yr}$ genes in these isolated lines (Dubekova et al., 2020). The identified lines combine high economically valuable traits (productivity) and resistance to yellow rust; therefore, they are of the greatest immunological value. They are recommended for further study and breeding improvement of the local agroecotype of winter wheat.

To achieve long-term control of pathogens, the key element is the introduction of new effective and diverse resistance genes into varieties, as noted in the research done by scientists (Shamanin et al., 2019). Thus, when studying a set of hexaploid synthetic wheat varieties, in 2016 and 2017, scientists identified valuable samples resistant to rust, powdery mildew and septoria, obtained from crossing winter durum wheat (Triticum turgidum sp. Durum) with various varieties of wheat. Previously, well-known highly effective genes were identified on Kazakh varieties, such as Dastan (Yr5), Karasai, Mereke 70, Naz and Akdan (Yr10), Yubileynaya 60, Dastan (Yr15) and a complex of genes (Yr18/Lr34 ) on such varieties as Ramin, Nurek, Mereke 70, Mayra, Bezostaya 1 and Almaly (Kokhmetova et al., 2014b; Esenbekova and Kokhmetova, 2016). However, an annual study of local breeding and the world collection, monitoring the expressiveness of isogenic lines, shows that the varieties and lines previously established as rust-resistant are now affected by infection up to $20-70 \%$ in the field. The loss of resistance to the pathogen in varieties and lines may be associated with the emergence, in recent years, of new virulent rust races (Hovmøller et al., 2018; Rsaliyev and Rsaliyev, 2018; Rsaliyev et al., 2020; El-Orabey, 2018). In this regard, it is advisable to create varieties with longterm stability, much more effective in preserving the crop.

For many years, markers of resistance genes to major diseases of grains have been identified and used by the international community in this direction. Thus, scientists carried out pyramiding of various Resistance genes (R) into breeding lines and identified their presence in Canadian winter wheat varieties that were released as part of the winter wheat breeding program at the Lethbridge Research and Development Centre, Agriculture and Agri-Food Canada (Laroche et al., 2019). Kazakh scientists are also conducting research in this field (Kokhmetova and Esenbekova, 2011; Kokhmetova et al., 2014a) and we are continuing the analysis of the selected breeding lines of winter wheat for further study of the presence of resistance genes on the immunological parameters. The cultivation of genetically resistant varieties is the most effective, economically and environmentally reliable method of disease control. 


\section{Conclusion}

Thus, the evaluation of the breeding material in the field, against the background of artificial rust infection, showed that the majority $(79.2 \%)$ of the lines of bread and durum wheat were characterized as MS and S to the pathogen. Concerning the reaction to Puccinia striiformis, 2 immune lines of bread wheat showed no signs of the disease. 4 lines of durum wheat and 1 line of bread wheat demonstrated $\mathrm{R}$ to the pathogen. Research work on the evaluation and selection of breeding material for immunological characteristics is relevant and requires further study and improvement to accelerate the process of creating highly productive varieties with improved immunological parameters that meet the production requirements.

\section{Author's Contributions}

All authors equally contributed in this study.

\section{Ethics}

This article is original and contains unpublishedmaterial. The corresponding author confirms that allother authors have read and approved the manuscript andno ethical issues have been involved.

\section{References}

Chen, X. M. (2005). Epidemiology and control of stripe rust [Puccinia striiformis f. sp. tritici] on wheat. Canadian journal of plant pathology, 27(3), 314-337. doi.org/10.1080/07060660509507230

Dubekova, S. B., Eserkenov, A. K., Ydyrys, A. A., \& Kuresbek, A. (2020). Analiz sostoyaniya ustoichivosti ozimoi pshenitsy k zheltoi rzhavchine v usloviyakh yugo-vostoka Kazakhstana [Analysis of the state of resistance of winter wheat to yellow rust in the south-east of Kazakhstan]. Izdenister, nätijelerIssledovaniya, rezultaty, 4, 214-220. doi.org/10.37884/.v4i4.42

El-Orabey, W. M. (2018). Virulence of some Puccinia triticina races to the effective wheat leaf rust resistant genes Lr 9 and Lr 19 under Egyptian field conditions. Physiological and Molecular Plant Pathology, 102, 163-172. doi.org/10.1016/j.pmpp.2017.12.006

Esenbekova, G. T., \& Kokhmetova, A. M. (2016). Küzdik bïday sorttarınan sarı tat (Puccinia striiformis f. sp. tritici) awrına tözimdi gen ïelerin ïdentïfikacïyalaw [Identification of genes resistant to yellow rust (Puccinia striiformis f. sp. tritici) in winter wheat varieties]. Izdenister, nätïjeler-Issledovaniya, rezultaty, 1, 96-102.

http://izdenister.kaznau.kz/files/full/2016_1.pdf
Esimbekova, M.A., K.B. Mukin, A.I. Abugalieva, K. Abdrakhmanov, S. Dubekova \& A.I. Morgunov. (2019). Geneticheskie resursy v selektsii pshenitsy na ustoichivost $\mathrm{k}$ tverdoi golovne [Genetic resources in wheat breeding for stinking smut resistance]. Agrarnayanauka, 1: 22-26.

doi.org/10.32634/0869-B 155-2019 -326-1-22-26

FAO. (2017). Borba s formami rzhavchiny pshenitsy: Ukruplenie natsionalnogo potentsiala i mezhdunarodnogo sotrudnichestva [Combating forms of wheat rust: Building national capacity and international cooperation]. Informatsionnye broshyury, 2. http://www.fao.org/3/b-i6918r.pdf

Goncharov, N. P., \& Goncharov, P. L. (1993). Metodicheskie osnovy selektsii rastenii.

Hovmøller, M. S., Rodriguez-Algaba, J., Thach, T., Justesen, A. F., \& Hansen, J. G. (2018). Report for Puccinia striiformis race analyses and molecular genotyping 2017, Global Rust Reference Center (GRRC), Aarhus University, Flakkebjerg, DK-4200 Slagelse, Denmark. Published online on 10 February, 2018. URL: http://wheatrust. org/(дата обращения 10.02. 2018.). https://agro.au.dk/fileadmin/Summary_of_Puccinia_ striiformis_race_analysis_2017.pdf

Hovmoller, M. S. (2017). New races caused epidemics of yellow rust in Europe, East Africa and Central Asia in 2016.

Koishybaev, M. (2010). Rol ustoichivykh k boleznyam sortov $\mathrm{v}$ integrirovannoi zashchite pshenitsy [The role of disease resistant varieties in integrated wheat protection]. Zashchita i karantin rastenii, 3: 30-33.

Koishybaev, M. (2018). Bolezni pshenitsy [Wheat diseases]. Prodovolstvennaya i selskokhozyaistvennaya organizatsiya OON (FAO), Ankara. ISBN: 978-92-5-130142-5, pp: 365. http://www.fao.org/publications/card/en/c/I8388RU/

Kokhmetova, A., \& Esenbekova, G. (2011). Molecular screening of wheat germplasm resistant to wheat leaf and stripe rust in Kazakhstan. Current Opinion in Biotechnology, (22), S47. doi.org/10.1016/j.copbio.2011.05.122

Kokhmetova, A., Sapakhova, Z., Madenova, A., Atishova, M., Yessenbekova, G., \& Galymbek, K. (2014a). Identification of wheat germplasms resistant to leaf and stripe rust using molecular markers. Journal of Biotechnology, (185), S29. doi.org/10.1016/j.jbiotec.2014.07.099

Kokhmetova, A. M., Sapakhova, Z. B., Madenova, A. K., \& Esenbekova, G. T. (2014b). Identifikatsiya nositelei genov ustoichivosti $\mathrm{k}$ zheltoi Yr5, Yr10, Yr15 i buroi rzhavchine Lr26, Lr34 na osnove molekulyarnogo skrininga obraztsov pshenitsy [Identification of carriers of genes resistant to yellow rust Yr5, Yr10, Yr15 and leaf rust Lr26, Lr34 based on molecular screening of wheat samples]. Biotekhnologiya. Teoriya i praktika, 1, 71-78. 
Kurmanbayeva, M., Sekerova, T., Tileubayeva, Z., Kaiyrbekov, T., Kusmangazinov, A., Shapalov, S., ... \& Bachilova, N. (2021). Influence of new sulfurcontaining fertilizers on performance of wheat yield. Saudi Journal of Biological Sciences. doi.org/10.1016/j.sjbs.2021.04.073

Laroche, A., Frick, M., Graf, R. J., Larsen, J., \& Laurie, J. D. (2019). Pyramiding disease resistance genes in elite winter wheat germplasm for Western Canada. $\begin{array}{llll}\text { The Crop Journal, } 7 & \text { (6): } 739-749 .\end{array}$ doi.org/10.1016/j.cj.2019.08.005

Lyon, B., \& Broders, K. (2017). Impact of climate change and race evolution on the epidemiology and ecology of stripe rust in central and eastern USA and Canada. Canadian Journal of Plant Pathology, 39(4), 385-392. doi.org/10.1080/07060661.2017.1368713

Martinez-Moreno, F., \& Solis, I. (2019). Wheat rust evolution in Spain: An historical review. Phytopathologia Mediterranea, 58(1), 3-16. https://www.torrossa.com/en/resources/an/4522720\# page $=5$

McIntosh, R. A., Dubcovsky, J., Rogers, W. J., Morris, C., \& Xia, X. C. (2017). Komugi Wheat Genetic Resources Database. Catalogue of gene symbols for wheat: 2017 supplement.

https://shigen.nig.ac.jp/wheat/komugi/genes/macgen e/supplement2017.pdf

Morgounov, A., Pozherukova, V., Kolmer, J., Gultyaeva, E., Abugalieva, A., Chudinov, V., ... \& Shamanin, V. (2020). Genetic basis of spring wheat resistance to leaf rust (Puccinia triticina) in Kazakhstan and Russia. Euphytica, 216(11), 1-15. doi.org/10.1007/s10681-020-02701-y

Park, R., Fetch, T., Hodson, D., Jin, Y., Nazari, K., Prashar, M., \& Pretorius, Z. (2011). International surveillance of wheat rust pathogens: Progress and challenges. Euphytica, 179(1), 109-117. doi.org/10.1007/s10681-011-0375-4

Peterson, R. F., Campbell, A. B., \& Hannah, A. E. (1948). A diagrammatic scale for estimating rust intensity of leaves and stem of cereals. Canadian Journal of Research, 26: 496-500. doi.org/10.1139/cjr48c-033

Prasad, P., Savadi, S., Bhardwaj, S. C., \& Gupta, P. K. (2020). The progress of leaf rust research in wheat. Fungal Biology, 124(6), 537-550. doi.org/10.1016/j.funbio.2020.02.013

Qi, T., Guo, J., Liu, P., He, F., Wan, C., Islam, M. A., ... \& Guo, J. (2019). Stripe rust effector PstGSRE1 disrupts nuclear localization of ROS-promoting transcription factor TaLOL2 to defeat ROS-induced defense in wheat. Molecular plant, 12(12), 1624-1638. doi.org/10.1016/j.molp.2019.09.010

Roelfs, A. P. (1992). Rust diseases of wheat: Concepts and methods of disease management.

Cimmyt.http://hdl.handle.net/10883/1153
Rsaliyev, A. S., \& Rsaliyev, S. S. (2018). Principal approaches and achievements in studying race composition of wheat stem rust. Vavilovskij Zbreve urnal Genetiki i Selekcii/Vavilov Journal of Genetics and Breeding, 22(8), 967-977.

doi.org/10.18699/VJ18.439

Rsaliyev, A., Yskakova, G., Maulenbay, A., Zakarya, K., \& Rsaliyev, S. (2020). Virulence and race structure of Puccinia graminis f. sp. tritici in Kazakhstan. Plant Protection Science, 56(4), 275-284.

Rsaliyev, A. S. (2011). Patotipy steblevoi rzhavchiny pshenitsy v Kazakhstane [Wheat stem rust pathotypes in Kazakhstan]. Zashchita i karantin rastenii, 10: 41.

Rsaliyev, Sh. S., Agabaeva, A. Ch., \& Rsaliyev, A. S. (2013). Dinamika izmeneniya populyatsii zheltoi rzhavchiny pshenitsy (Puccinia striiformis f. sp. tritici) v Kazakhstane. Problemy mikologii i fitopatologii v XXI veke [Dynamics of changes in the population of wheat yellow rust (Puccinia striiformis f. Sp. Tritici) in Kazakhstan. Problems of mycology and phytopathology in the XXI century]. Materialy mezhdunarodnoi nauchnoi konferentsii [Materials of the international scientific conference], Natsionalnaya akademiya mikologii, Oct. 2-4, KopiR Grupp, Sankt-Peterburg, Russia, pp: 231-234. ISBN: 978-5-905064-66-1.

RSG. (1986). CIMMYT, Mexico, D.F. http://hdl.handle.net/10883/1109

Shamanin, V., Shepelev, S., Pozherukova, V., Gultyaeva, E., Kolomiets, T., Pakholkova, E., \& Morgounov, A. (2019). Primary hexaploid synthetics: Novel sources of wheat disease resistance. Crop Protection, 121, 7-10. doi.org/10.1016/j.cropro.2019.03.003

Solh, M., Nazari, K., Tadesse, W., \& Wellings, C. R. (2012, September). The growing threat of stripe rust worldwide. In Borlaug Global Rust Initiative (BGRI) conference, Beijing, China (pp. 1-4).

https://globalrust.org/sites/default/files/posters/solh_ 2012.pdf

Urazaliev, R. A. (2011). Rastenievodstvo [Plant growing]. Doklady Natsionalnoi akademii nauk Respubliki Kazakhstan, 3, 18-34.

http://nblib.library.kz/elib/library.kz/journal/Urazali ev.pdf

Urazaliev, R., Yessimbekova, M., Mukin, K., Chirkin, A., \& Ismagulova, G. (2018). Monitoring of Aegilops L. local species genetic diversity of Kazakhstan's flora. Vavilov Journal of Genetics and Breeding, 22 (4), 484-490. doi.org/10.18699/VJ18.386 
Urazaliev, R. A. (2019). Evolyutsiya adaptivnoi selektsii pshenitsy $\mathrm{v}$ Kazakhstane i sopredelnykh stranakh TsAZ (100 letnii period 1917-2017 gg.) [Evolution of adaptive wheat breeding in Kazakhstan and neighboring Central Asian countries (in 100 years from 1917 to 2017)]. Optimizatsiya selektsionnogo protsessa - faktor stabilizatsii i rosta produktsii rastenievodstva Sibiri: Mat-lymezhdun. konf., provedennoi v ramkakh vyezdnogo 46-go zasedaniya Obedinennogo nauchnogo i problemnogo soveta po rastenievodstvu, selektsii, biotekhnologii i semenovodstvu OUS SO RAN po selskokhozyaistvennym naukam, posvyashchennoi 90-letiyu akademika RAN P.L. Goncharova i 50letiyu SO RASKhN [Optimization of the breeding process as a factor of stabilization and growth of crop production in Siberia: Materials of an international conference held at the 46th meeting of the Joint Scientific and Problem Council on Plant Growing, Breeding, Biotechnology and Seed Production of the Joint Scientific Council of the Siberian Branch of the Russian Academy of Sciences (OUS SO RAN) on agricultural sciences dedicated to the 90th anniversary of Academician P.L. Goncharov and the 50th anniversary of the Siberian Branch of the Russian Academy of Agricultural Sciences], Jul. 2326, Izd-vo IF FITs KNTs SO RAN, Krasnoyarsk, Russia, pp, 13-20. ISBN: 978-5-6042995-2-4. https://ksc.krasn.ru/upload/medialibrary/0b9/0b94c6 cee3826ba952f4edfd6be23c98.pdf
Volkova, G. V., Kudinova, O. A., \& Miroshnichenko, O. O. (2020). Steblevaya rzhavchina - osobo opasnoe zabolevanie pshenitsy [Stem rust: A particularly dangerous wheat disease]. Dostizheniya nauki i tekhniki APK, 34 (1), 20-25. doi.org/10.24411/0235-2451-2020-10104

Ydyrys, A., Sarbaev, A., Morgounov, A., Dubekova, S., \& Chudinov, V. (2020). Isogenic Lines: Reaction to the Kazakhstan Population of Stem Rust (Puccinia graminis f. sp. triticia). AGRIVITA, Journal of Agricultural Science, 43(1). doi.org/10.17503/agrivita.v43i1.279 